\title{
QUO VADIS CIVITAS? - THOUGHTS ON THE EUROPEAN CONCEPTION OF THE CITY TODAY
}

"The history of civilization is the progressive reading of spirit into matter." (Swami Vivekananda)

"History is movement of spirit in time." (Hegel)

The city is an artefact created by man. In fact it is not only an artefact consisting of buildings, but also an organism consisting of people and functions. The city has a long history from the Pharaohs' Egypt to Mesopotamia via ancient Greece and Rome. Though no absolutely exact time or place of the origin can be said, it is known, however, that there have been cities for over 5000 years. Archaeological excavations constantly produce new information on ancient cities, even on those, which have vanished a long time ago. The mythical story of Atlantis is still captivating our minds.

The ancient city, medieval city, Renaissance city and Baroque city... All periods have created their own urban ideals. In the $18^{\text {th }}$ century, the conception of the city started to change radically. After the period of classicism, the city was no longer thought to be an architectural entity, and urbanism was born. Laws and different regulations were written and principles of urban building were defined. Industrial society was born in the $19^{\text {th }}$ century and the history of the modern city starts from 


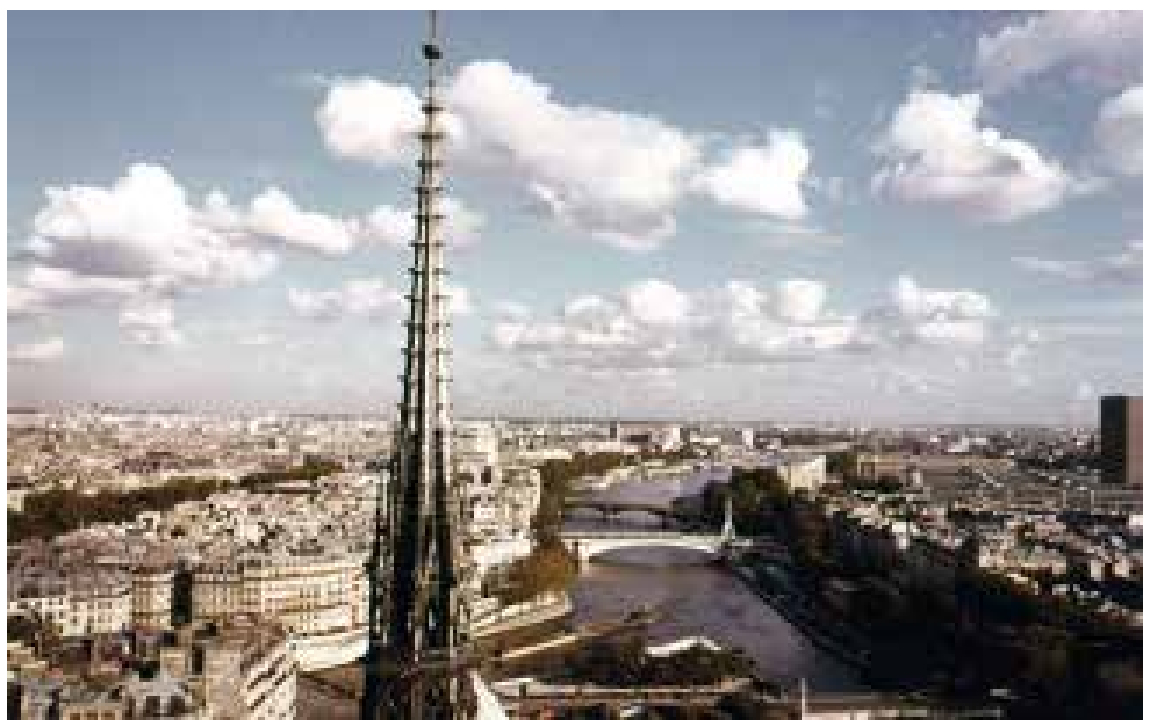

Fig. 1. 2000 years of history - a view over the historical city centre of Paris (photo Kaisa Broner-Bauer)

the same period. Traffic, strategy and hygiene as well as functionalism and economy became the central themes for the modern urban ideal. The 100-year history of urban planning during industrial society is an interesting story about how belief in progress and utopian thinking have influenced man's living environment.

As opposed to the urban cultures prevailing in traditional and modern industrial societies, our time has generated totally new urban phenomena. One of them is the so-called post-modern urban nomadism. Post-modern nomadism means a global citizen's multicultural, moving and rootless way of life, when home is changed from one place to another, from one city to another and often even from one country to another. As a result of this extreme mobility, linked with globalisation which concerns all and everything, the traditional typology of the cities has also started to change.

We live a period of unparalleled change. For the first time one has become conscious of the biocapacity of the globe having its limits, and a more holistic understanding of life on our planet, a kind of cosmic consciousness, is being born. Mankind as a whole is concerned. Former ways of thinking and acting from one's own narrow utilitarian point of view have ceased to function. Urbanism is at a turning point. Concepts 
go out of date or lose their meanings, when the clash of old and new is fiercer than ever. There is a need to revise the concepts of city planning and devise new means of analysis in order to more sensitively perceive and take into account the "weak signals" in urban life. Now it is the time to ponder, what kind of city we really want to have today. ${ }^{1}$

\section{WHAT IS THE CITY?}

In primitive communities, people's way of life developed from nomadism to permanent village communities and gradually to cities. Safety considerations were often the decisive factor, when permanent village communities had their origins about 15000 years ago, as was the case with later in urban building, too. In prehistoric times, cemeteries also furthered the development of permanent village communities. It seems that concentrated burial places, "cities of the dead", preceded the origin of proper cities. ${ }^{2}$ We also know, for instance, that the Mesopotamian city of Uruk, which was the world's largest agglomeration in the third millennium B.C., owed its creation to climate change: water was suddenly scarce and people rushed to live near to where it was available. ${ }^{3}$

Numerous different factors have influenced the birth of cities, and there are several different types of cities known in urban history. Max Weber, a German sociologist and one of the pioneers of Western urban sociology, has written his famous text Die Stadt, in English The City, which deals with historical types of cities. ${ }^{4}$ It is a historical-sociological analysis about the development of cities from Antiquity to the Middle Ages. In his book, Weber creates a kind of urban typology based on juridical, political and economic facts. Weber classifies cities according to so-called "Idealtypen" (ideal types), which, however, can only be mixed types in reality. The starting points of the classification are the organizational model, functions and relationships between social groups or classes of the city.

$1 C f$. the statement of Mikko Aho, the head of Helsinki City Planning Department regarding a proposal by the inhabitants to create a new multipurpose green channel in the city centre: "This is the right time to discuss what the city can be about."Marja Salmela, "Baana voisi kuhista elämää. Vapaaehtoisten joukko ideoi kevyen liikenteen väylästä kaupungin vihreän selkärangan”, Helsingin Sanomat, 19.4. 2013: A 20.

2 Lewis Mumford, La cité à travers l'histoire (Paris: Editions du Seuil, 1964), 13.

3 Cf. Uruk 5000 Jahre Megacity, archaelogical exhibition 25.4.-8.9.2013, Pergamonmuseum, Berlin.

4 Originally published in 1921 in Archiv für Sozialwissenschaft und Sozialpolitik, vol. 47. 
When describing the development of city types, Weber emphasizes the originality of occidental civilization: it was in Europe where the phenomenon of the free urban community had its origin. This kind of urban community was completely independent, in other words it had its own political, juridical and economic orders. Although all medieval European cities did not function under the principles of a free community, this phenomenon has had a significant impact on the development of European urban culture. In this process, Weber pays attention to the significance of Christianity as well as to the rise of the bourgeoisie and gradually culminating class conflicts, which finally in the $19^{\text {th }}$ and $20^{\text {th }}$ centuries, according to Marxist terminology, were to lead to an open class struggle in industrial society.

There are numerous definitions of the city, and history has shown that each epoch transforms the city according to its own conception of it. Max Weber starts the first chapter of his book The City as follows:

The many definitions of the city have only one element in common: namely that the city consists simply of a collection of one or more separate dwellings but is a relatively closed settlement. Customarily, though not exclusively, in cities the houses are built closely to each other, often, today, wall to wall. This massing of elements interpenetrates the everyday concept of the "city" which is thought of quantitatively as a large locality. In itself this is not imprecise for the city often represents a locality and dense settlement of dwellings forming a colony so extensive that personal reciprocal acquaintance of the inhabitants is lacking. ${ }^{5}$

In fact, one of the main criteria of the city is that it is a kind of cluster - a historical city often surrounded by a wall - consisting of several different city blocks and parts. Only in the case of this kind of cluster of dwellings, can we talk about a city. On the other hand, the city must be seen as a historical process influenced by social development. Aldo Rossi has expressed this in the words, "the city is a place where the deposits of history are condensed". 6 This definition brings up the view that the city is an agglomeration, which has developed during generations and consists

5 Max Weber, The City (Glencoe, Illinois: Free Press, 1958), 65.

6 Aldo Rossi, L'architecture de la ville (Paris: L'Equerre, 1981), 167. 
of quintessentially different historical layers. It is also noteworthy that the word "civilization" has the same etymological origin, as the word city, cité (Latin civitas). The history of European civilization is essentially intertwined with the history of cities and urban culture development.

Where man in archaic societies built the city according to an archetype and consecrated it to God, as Mircea Eliade has described in his books, ${ }^{7}$ Western urban agglomeration is a phenomenon produced by the profane world. In post-industrial society, the tertiary sector is the dominating one, but nowadays it is dominated by a worldwide information network related to internationalism and demographic revolution. There has been a huge change in the scale. More and more large cities are springing up, with millions of inhabitants. Today the city is a multi-dimensional and multidisciplinary phenomenon. At the moment, there seems to be some kind of searching for a new urban philosophy, suggesting that our conception of the city is in a process of change.

\section{PARADIGMS OF URBAN THINKING}

While urban development is influenced by multiple factors, the processes of city planning and decision-making are guided by our own internal view on what the city is and what we think it should be like. I call this internal view of the city "conception of the city". It is more or less unconsciously influenced by different values and traditions prevailing in society, social and cultural processes as well as implicitly by the conception of the world provided by science. These form paradigms of thinking, which influence our actions and are then reflected in the physical environment through planning. In other words, the paradigms we have accepted have their impacts on the models according to which we plan, build and work up our living environment. The French urban sociologist Henri Lefèbvre has stated that "(social) space is a (social) product". ${ }^{8}$ This also means that people's different mental and material endeavours as well as the values, conflicts and problems included in them come out in the built environment; they express themselves sym-

7 See e.g. Mircea Eliade, Le mythe de l'éternel retour. Archétypes et répétition (Gallimard: Paris, 1969), 14-48, Mircea Eliade, Briser le toit de la maison. La créativité et ses symboles (Paris: Gallimard, 1986), 205-216.

8 Henri Lefèbvre, La production de l'espace (Paris: Editions Anthropos, 1974), 35. 


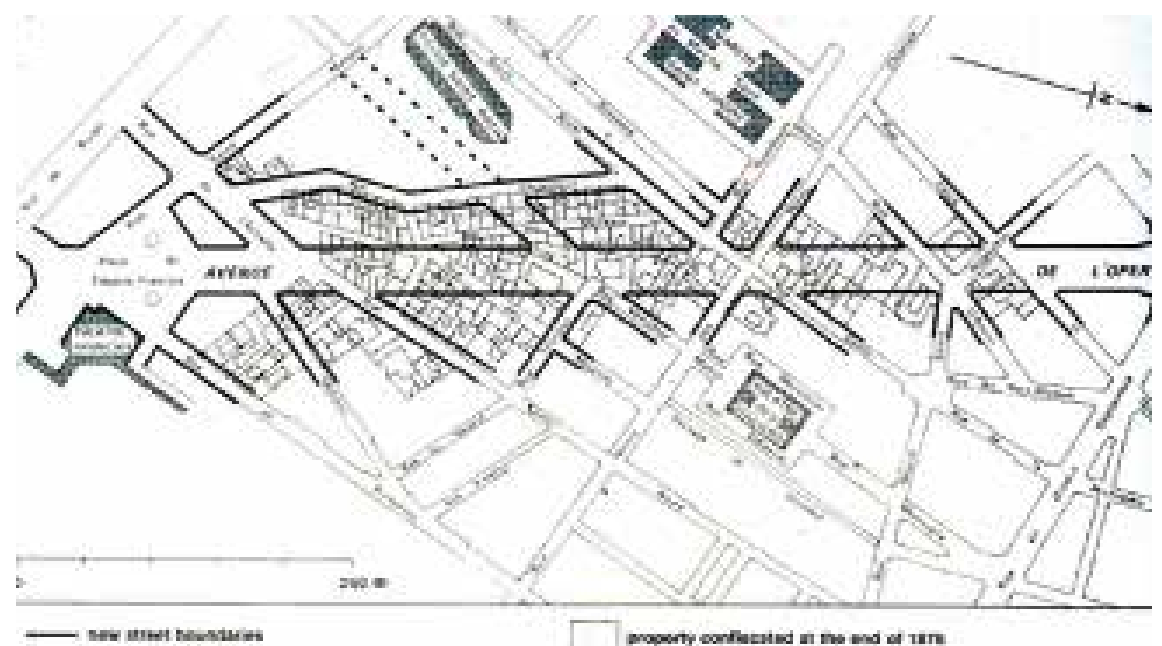

Fig. 2. Restructuration of medieval Paris for the purposes of traffic and strategy, plan 1876

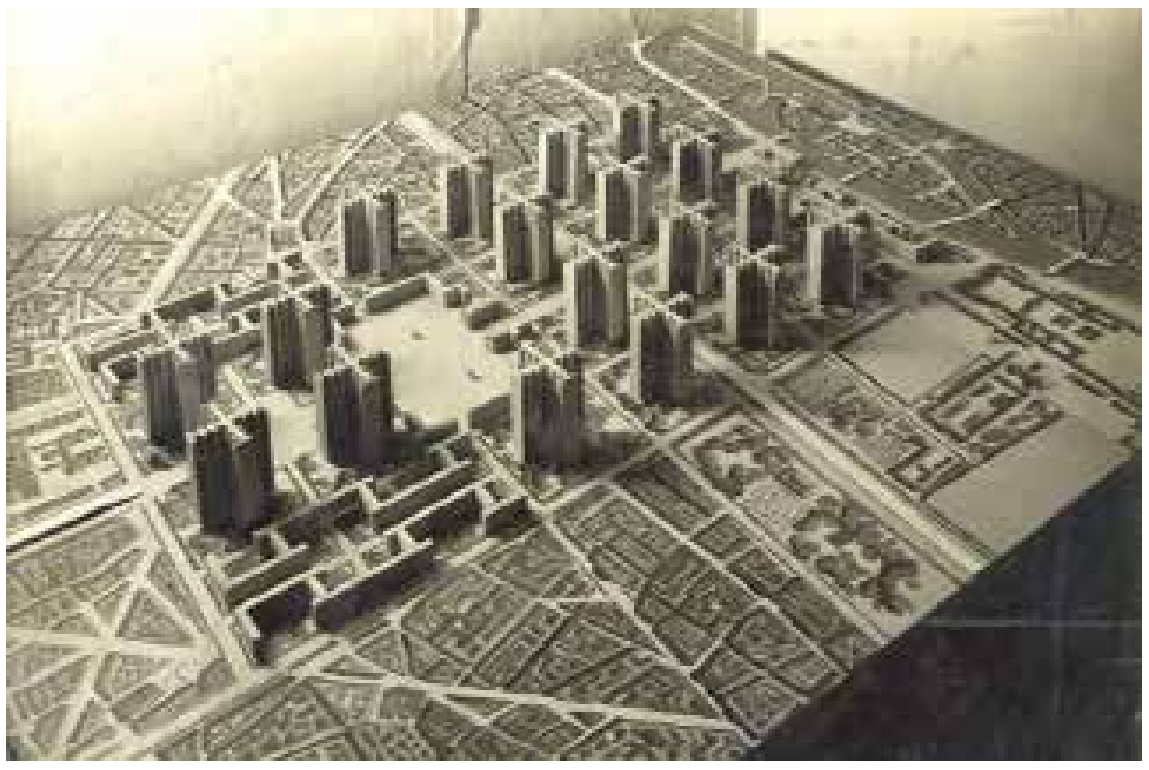

Fig. 3. "Plan voisin" for the historical city centre of Paris, Le Corbusier 1925

bolically in the physical nature of the city. In that sense, we can say that the city is a collective image of our human existence.

What are then the paradigms, which have influenced urban thinking and affect the change process of the city in our times? What kind of 


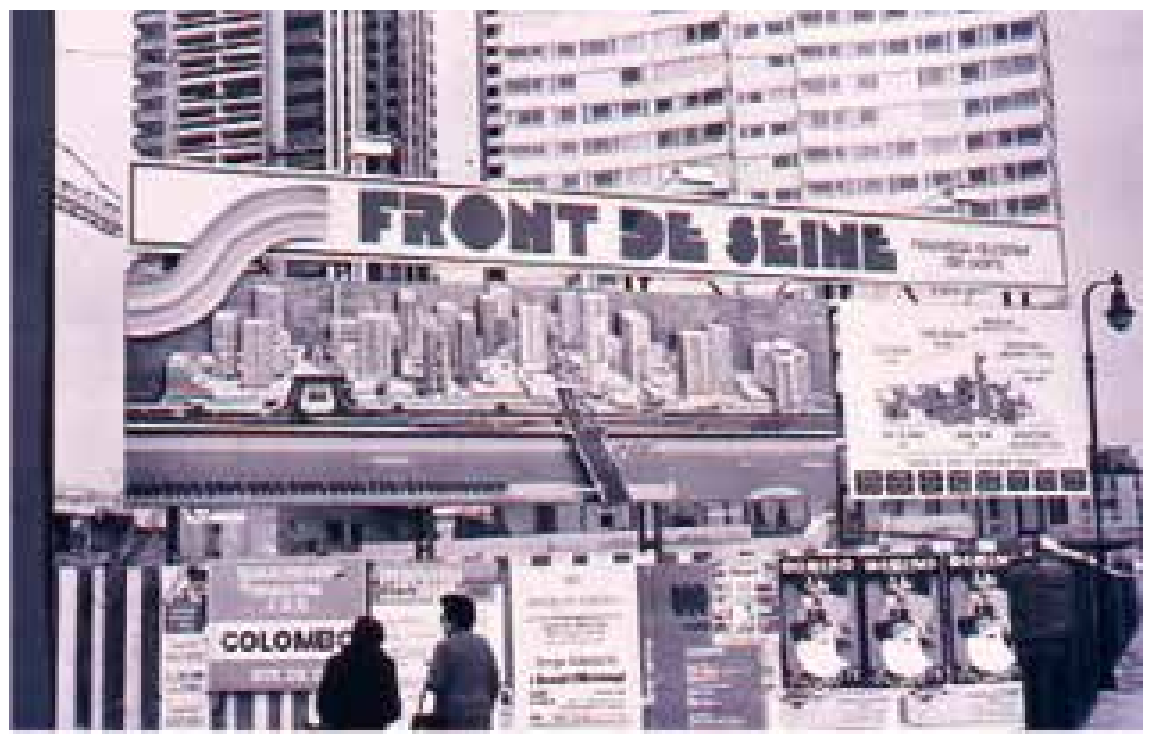

Fig. 4. "City as merchandise", Paris - Front de Seine 1975 (photo Kaisa Broner-Bauer)

conception of the city are we forming today? Through ages, each generation has formed its own view of what the city is, and what the ideal city is. Forming a conception of the city is always a historical process. The European conception of the city has developed, become refined and changed during centuries. In the $20^{\text {th }}$ century, it resulted in the urban ideal of industrial society, the modern city, which was after all the complete antithesis of the traditional conception of the city. During the last few decades, discussion about the essential nature of the city has again become more active, especially when related to critique of modernism. ${ }^{9}$

Modernism was an ideological project with equality, democracy and social progress as its ideals. This all was believed to be obtained along with development of science and technology on a linear time axis, on which space was understood as a constant. The modern city was seen as a functional system, while the historic city was considered to be unhealthy and unsuitable for the modern way of life. Modernist belief in the progress resulted in vast destruction of old quarters of cities and traditional environments. Everywhere in the world, they were replaced by

9 Cf. Kaisa Broner-Bauer, "Lost Utopia. Thoughts on the Dilemma of the Modern City", Urban Forms, Suburban Dreams, ed. by Malcolm Quantrill, Bruce Webb (College Station: Texas A\&M University Press, 1993), 15-28. 


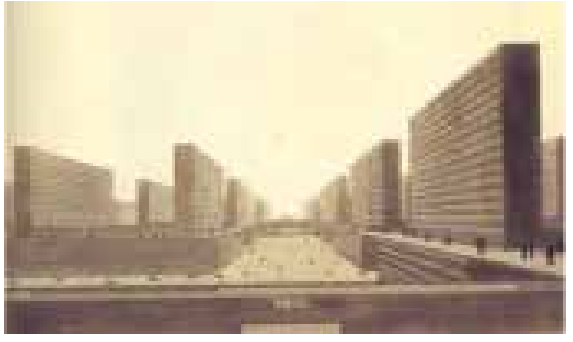

Fig. 5. Modern City - Vertical City, Ludwig Hilberseimer 1927

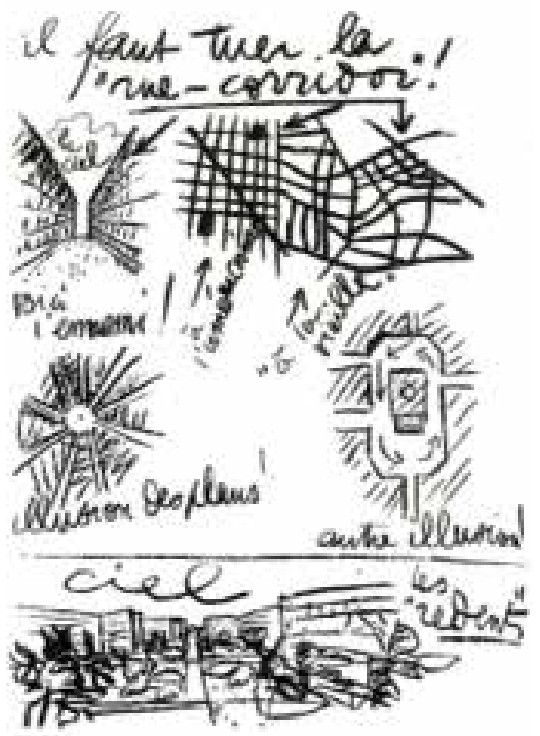

Fig. 6. "Il faut tuer la 'rue-corridor'!" "We must kill the 'corridor street'!" Le Corbusier 1929 new urban environments, more or less identically built spaces resembling each other. Urban building was also thought to be "industrial production", it produced urban space, and urban space became prosaically a merchandise.

The ideology of modern city planning became finally a quite one-sided doctrine, in spite of the fact that in the period of the CIAM (Congrès Internationaux d'Architecture Moderne) there were also other kinds of urban thinking counterbalancing The Athens Charter (1928), anonymously published as a book in $1943^{10}$ and later by Le Corbusier under his own name. ${ }^{11}$ For instance, on the demand of Italian architects, the question of urban heritage was added to the four major functions of the city as first defined by the CIAM. ${ }^{12}$ There were also urban planners who propagated an organic conception of the city. A pioneering theorist was the Englishman Patrick Geddes whose books on urbanism at the beginning of the $20^{\text {th }}$ century were well ahead of their time. For example, one of the central ideas presented by Geddes in his book Cities in Evolution (1915) was that the key question of urban planning is to link the city's own

10 Le Groupe CIAM-France, Urbanisme des C.I.A.M. La Charte d'Athènes (Paris: Plon, 1943).

11 Le Corbusier, La Charte d'Athènes (Paris: Editions de Minuit, 1957).

12 Ibid. inhabiting, working, recreation and circulation, to which the question of heritage was added. 


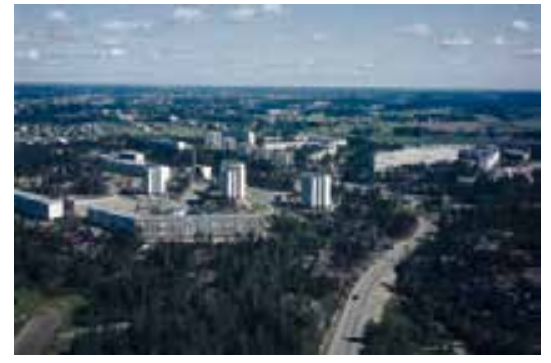

Fig. 7. Helsinki - Pihlajamäki 1966 (photo Sky-Foto Möller) past with its future. It took almost a hundred years before this view has been more generally accepted.

Certainly it is true that there was also a kind of huge progress included in modern city plans; they improved the level of dwelling and also solved many functional problems of modern communities. Sometimes one also managed to build a good and harmonious new urban environment of aesthetic quality. For example, Tapiola, the modern garden city built in the 1950's and 60's in Espoo, near Helsinki, became world-famous. However, maybe the best Finnish example manifesting the urban thinking of the period is the project development of Pihlajamäki in the eastern part of Helsinki. The ideal was to build a whole suburban area with a uniform cityscape, which was planned and built by one and the same developer. All the buildings were carried out through serial production and the same type of contract. Economy, serial production and uniformity were key words of the 1960's.

An important step towards re-evaluation of the principles of modern city planning was the congress organised by the Council of Europe in Amsterdam in $1975 .{ }^{13}$ As a result of the congress, the Committee of Ministers of the Council of Europe published a report entitled The Declaration of Amsterdam. The declaration highlighted not only a greater public responsibility for urban rehabilitation and conservation of the architectural heritage but also the idea of integrated conservation, which was brought up as a holistic goal to which the authorities of all the member countries should commit themselves. Integrated conservation implies a public policy of conservation and maintenance of the built environment in which local inhabitants and activities are also taken into consideration. The declaration states notably that "the rehabilitation of old areas should be conceived and carried out in such a way as to ensure that

13 Even before that a significant move in the history of urbanism was made in the US when the City of New York reformed its planning system in the early 1970's. At that time, for the first time in a western country, CIAM's zoning theory was abandoned as the basis for modern city planning when the manufacturing blocks of SoHo were designated as a mixed-use district in 1971. Cf. Kaisa Broner, New York face à son patrimoine (Brussels: Pierre Mardaga, 1986). 
(...) [it] does not necessitate a major change in the social composition of the residents". Interestingly the recommendations and conclusions of the congress already envisaged the ideological principles of sustainable development by commenting on resource-saving measures and by stressing the importance of social and cultural diversity in the old parts of towns. Although the idea of sustainable development did not exactly rise to public attention until the following decade, a clear move towards a new planning ideology based on conservation was already crystallized in the recommendations of Amsterdam:

A new type of town planning is seeking to recover the enclosed spaces, the human dimensions, the inter-penetration of functions and the social and cultural diversity that characterizes the urban fabric of old towns. But it is also being realized that the conservation of ancient buildings helps to economize resources and combat waste, one of major preoccupation of present-day society. It has been proven that historic buildings can be given new functions, which correspond to the needs of contemporary life. ${ }^{14}$

A planning concept corresponding to integrated conservation is the so-called preservation planning, which became prevalent in the United States and Europe in the last few decades of the $20^{\text {th }}$ century. It aims at preserving the historical layers of the city, literally "linking the city's own past with its future". Preservation planning as well as the movement of critique of the CIAM conception of the city were both more or less based on post-modern thinking and a new kind of relation to history. Even if that critique has sometimes been short-sighted, it has to be admitted that at least one false view was included in the modern conception of the city. A lot of traditional urban environments and buildings were destroyed, before people started to understand that the real nature of the city is not to be a functional system only, but the city is above all an expression of historical continuity and a valuable collective cultural heritage. The city is a significant situational scene of human experience and a determinant in the forming of the cultural identity of its inhabitants.

14 The Declaration of Amsterdam, 1-2 (Strasbourg: Directorate of Press and Information, 1975). 


\section{THE PRESENT STATE OF THE WORLD -}

\section{A CHANGE OF PARADIGM ${ }^{15}$}

In July 2002, the French newspaper Le Monde published an interview of Edgar Morin, a respected French sociologist. ${ }^{16}$ The headline of the page-sized newspaper article was a quotation by Morin: "Notre civilisation ne sécrète plus d'espérence", freely translated as "Our civilization does not arouse hope any more". In the interview, Morin specifies reasons for indisposition of modern society. According to him, technological and material progress has been followed by mental and moral underdevelopment. Morin says that the reason for this problem lies in our civilization itself. One-sided admiration of modernity has prevented us from understanding the hidden side of real progress. It has prevented us from seeing that scientific, technological and economic progress is no guarantee of human progress and it is not the same thing as mental well-being. Quantity has subordinated quality. Western emphasis of individuality has not gone hand in hand with development of collective responsibility, either, but has led to separatedness. Traditional collective joint responsibility has been replaced by anonymous organisations of limited responsibility. Our civilization arouses neither hope nor real solidarity. On the other hand, the dream of total control of the world, which has been fed by fast technological-scientific development, has to face incredible menaces caused by material progress. We have to become conscious of our interdependence not only with other people and nations, but also with the biosphere, the destruction of which would mean destruction of us as well. ${ }^{17}$

Today, big uncertainty seems to dominate the views of the future of mankind. Even if Edgar Morin's social critique is strictly realistic, it is not, however, totally devoid of hope. Morin considers the only hope to be the fact that we change our thinking - and our way of action. We have to learn to understand what the basic problems of mankind are, and to act responsibly to solve them. It is not enough that we act only locally or globally, because the different levels of action are in a complicated

15 The following three chapters are based on the author's essay "Mitä on eurooppalainen kaupunkikäsitys tänään?” published in Synteesi, 3 (2003).

16 Alexis Lacroix, Edgar Morin. "Notre civilisation ne sécrète plus d'espérence'. Face à un avenir de plus en plus chargé de menaces, le sociologue propose de parier sur l'utopie”, Le Monde, 20.7-21.7. 2002. 17 Ibid. 
way connected to each other. All actors are responsible, both individuals and societies, on all levels of action.

Concern over the future of mankind has come up in the opinions of representatives of almost all scientific and professional fields all around the world. Reasons for a mental vacuum have been searched for, the dead end of materialism has been revealed, pollution of the environment and its catastrophic consequences have been warned about and return to natural quality of living has been longed for. Urban planners have for their part thought over possibilities of influencing the state of affairs. Criteria of sustainable development, in the first instance, have been examined and put into practice.

Authorities have also adopted a serious attitude towards the question. For example in Finland, a paragraph was included in the Constitution of the country in 1999. According to it "Nature and its biodiversity, the environment and the national heritage are the responsibility of everyone. The public authorities shall endeavour to guarantee for everyone the right to a healthy environment and for everyone the possibility to influence the decisions that concern their own living environment." ( $\S$ 20) ${ }^{18}$ Correspondingly, the general objective of the present Land Use and Building Act of Finland is "to create the conditions for a good living environment and promote ecologically, economically, socially and culturally sustainable development". ${ }^{19}$ The aim is also to "ensure everyone a chance to participate in preparation of matters, quality of design and interactivity, the diversity of expertise and open communication in the present cases." (§1) In addition to this, the act in question defines the following objectives among others:

- The objective in land use planning is through interactive planning and sufficient assessment of impact to promote beauty of the built environment and the preservation of cultural values. ( $\$ 5$ paragraph 3)

- The objective of building guidance is to promote building based on approaches which have sustainable and economical life-cycle properties and are socially and economically viable, and create and maintain cultural values. ( $§ 12$ paragraph 2 )

18 The Constitution of Finland ([Finland]: Parliament of Finland, 2001).

19 Land Use and Building Act, \$1 (1999/2012). 


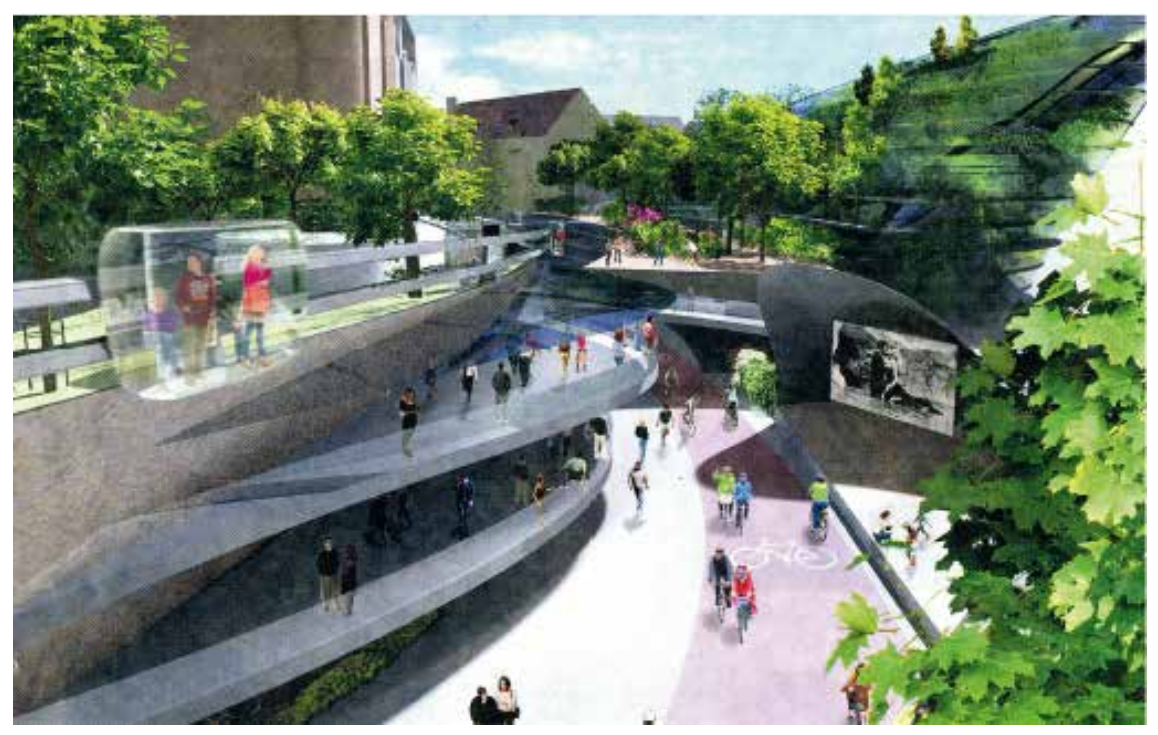

Fig. 8. UrBaana, a proposal for a multifunctional urban path by a groupe of inhabitants, Helsinki 2013 (visualization Kalle Ukonlinna, Helsingin Sanomat, 19.4.2013, www.urbaana.fi)

- The built and the natural environment must be preserved and their special values must not be destroyed. (§ 54)

Thus, the objectives of sustainable development in building and urban planning have been defined and recorded in the law in Finland, and the same kind of tendency prevails in other European countries as well. One important step has been taken as the public way of thinking has been officially changed. As the Land Use and Building Act of Finland for its part expects "interactive planning", "sufficient assessment of impact" and "building guidance", final responsibility for building a good environment falls in practice upon architects and planners of communities as well as authorities responsible for building guidance and control.

However, it is more difficult to find the means of reaching the general goals of building and land use planning than to define them. It is true that numerous conflicting forces, which are not always controlled by planners, have their impacts on the forming of the environment and the building of cities. One essential task of urban planning is to obtain a balance between the different dynamics present in the city space and influencing the urban process of change: the aspirations of users and those of wielders of power. 
As regards the present state of urban affairs, I would agree with Professor Panu Lehtovuori as he says: "Trying to understand a complex entity is challenging. The city is not easy to see in its totality. (...) In order to somehow be able to have control of a large sphere, we need interactive ways to construct visions together. Visualization is also a process: one constructs scenarios, which are tested. Through them one should be able to sieve out significant questions - to which answers are then to be sought after."20

\section{GLOBALISATION, POST-MODERN IDENTITY AND ESSENTIAL NATURE OF THE CITY}

The present on-going historic process, which post-modern culture is linked with, is called globalisation. Manuel Castells has analyzed the logics of supranational, global economic activity based on flows of information. ${ }^{21}$ The term "space of flows" used by him means the abstract space formed by present-day resource and information flows of power structures. "Space of flows" determines both structures of production and labour's way of life. When the ruling organizations are no longer dependent on traditional systems based on place, traditional social, economic and cultural structures also start to fall to pieces. Worldwide restructuration results in the fact that earlier significant places, cities and entire areas are disregarded and passed by, when their meanings as scenes of events disappear.

It can be asked what kind of places - or what kind of scenes of events - the cities are which get through today's global competition, and what their essential nature is. The nature of the city can be examined from many viewpoints. The theories related to place studies offer one approach. The city is "a locality", which consists of many and many kinds of places. There is a discussion about what an urban place is like, from where it gets its meaning content and what the identity factors of an urban place are. ${ }^{22}$ One starting point is clear: in the survey of all plac-

20 Minna Chudoba, "Panu Lehtovuori - professori teorian ja käytännön välissä”, Arkkitehtiuutiset, 3 (2013), 9.

21 See e.g. Manuel Castells, The informational city: information technology, economic restructuring, and the urban-regional process (Oxford: Blackwell, 1989); Manuel Castells, The information age: economy, society and culture (Oxford: Blackwell, 1996).

22 I have dealt with this theme, impacts of globalisation on meanings and change of identity of place in my article "Postmoderni identiteetti ja paikan merkitykset", Synteesi, 3 (2000). 
es, people who live in the place or somehow else influence its essential nature also have to be taken into consideration. Humanistic geographers, French researchers in particular, have as early as the end of the $19^{\text {th }}$ century emphasized the interactive relationship between man and his living environment, as well as the influence of local history and traditions on people's way of life. This approach still prevails in today's place studies, which instead of surveying spatial phenomena, prioritize human experience of space and aim at understanding the experiential context of place.

In the concept of place, the question is basically about human and cultural meanings. A place is space that has "meanings" in man's own world of experience. In other words, man creates a place by adding meanings to it ${ }^{23}$ This kind of definition does not have its emphasis only on an interactive relationship between man and a place but also on the subjective nature of a place experience. But collective experiences also have their influences on forming the identity of a place. Collective experiences of a place are produced by the shared history and way of life of people living in the same area, as well as the images of the place preserved in the collective memory. This is how local cultural appreciations, which can be called values of the place, are developed. These values conveyed by the collective memory form the field in which an individual also forms his/her own identity, which always happens in interaction with the place or places in which he/she lives.

In place studies during the last 20-30 years, new phenomena like fragmentation and dislocation have appeared, and breaking of the traditional space-time relationship is related to it. As the rhythm of life is faster and faster, and on the other hand, a still bigger part of our actions takes part in electronic abstract space, the borders of empirical space fall to pieces and lose their earlier meanings. Researchers have started to talk about "emptying of time", which means separation of space from place. ${ }^{24}$ As communication and meeting between people do not necessarily need a place any more, but social intercourse more and more often takes place in abstract space, the function of place changes. This inevi-

23 In humanistic geography this is a generally accepted way of understanding the essential nature of place. Cf. Tila, paikka ja maisema. Tutkimusretkiä uuteen maantieteeseen, ed. by Tuukka Haarni et al. (Tampere: Vastapaino, 1997).

$24 C f$. Tony Giddens in Jorge Larrain, Ideology and Cultural Identity: modernity and the Third World presence (Cambridge, Mass.: Polity Press, 1994), 151-152. 
tably has its impact on urban space as well, its functional structure as a place or places and their urban imago - as well as on forming the conception of the city of our time.

I still believe that in spite of the dependence on and domination of abstract space caused by "space of flows", man needs a psychic-physical experience of a concrete place and time, as well as continuity of this experience. In fact, however hard we try (for instance, by symbolic means of art), we can free ourselves from time and space by way of illusion or by leaving our body. This is the lot of man. Correspondingly, the city as a place or places is a functional-physical cluster created and built by man and above all, it is a dwelling place. If nobody lives in a city, it is not a city. As a dwelling place, the city means "anchoring" of our lives and identities in a certain historical time and place. In that sense, the city is a scene on which its inhabitants' lives take place, it is also their collective "self-portrait". However, in modern society, dwelling places and homes are changed more and more often, and more and more people have many homes at the same time. As several different periods and places are included in man's life cycle, they leave their traces and also make layers in his identity.

Unlike in traditional or modern societies, identity shaped by a post-modern cultural context is mosaic identity. With this term, I mean a fragmentary composition of what we are and what we want to be. It has been produced by many kinds of experiences of place and time. In traditional societies, the formation of identity was connected with historical tradition and cultural heritage, i.e. with place and time. In modern industrial societies, on the contrary, the formation of identity has been characterized by the future-oriented belief in progress linked with the linear conception of time, and at the same time by cultural separation from tradition and place. While identity is always a process, post-modern identity can be seen as a process independent of both time and place, but its formation is influenced by several simultaneous or occasional "adherences", or identifications with different experiences of time and place. Man with mosaic identity lives or has lived in many places; he is an inhabitant of "the global village", whose multicultural experiences are stored in his memory and form layers into his identity. ${ }^{25}$

25 I have earlier treated the topic in my article "Postmoderni identiteetti ja paikan merkitykset", Synteesi, 3 (2000). 


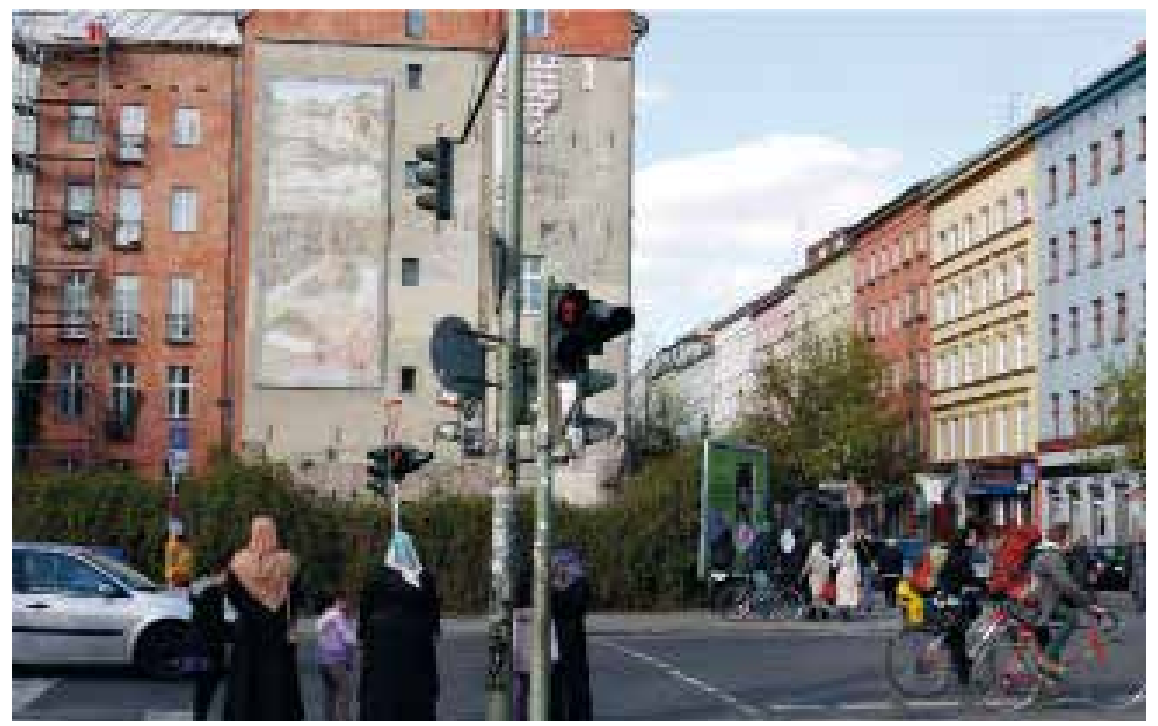

Fig. 9. Berlin - Kreuzberg, multicultural city life 2013 (photo Kaisa Broner-Bauer)

Correspondingly, we can talk about the layers of identity and the multicultural nature of the city. It makes us think about the meanings of the different layers - historical, cultural, aesthetical and social layers - in urban space. Their cooperative action and variations produce the local values of different parts of cities and its neighbourhoods. Although urban layers are often fragmented and even mutually conflicting, they, however, form a rich urban entity, a living "collage city", the "memory" of which has stored inhabitants' collective experiences and values refined by them. This kind of collage city inherited from past periods and expressing different local cultures should be seen as an important resource for the future development of a city.

Inhabitants themselves are the basic resource for urban development. They influence the birth of the mental atmosphere, the cultural ethos of the place. As Richard Florida has shown in his bestseller The Rise of the Creative Class (2002), cities succeeding in the modern economic competition are places which are able to attract creative people. According to Florida, organizations offering jobs are no longer determining factors in the logic of regional development, but the mover of the competition between regions is a new "creative social class", in other words talented people who above all want to realize their own, creative ways of life and 


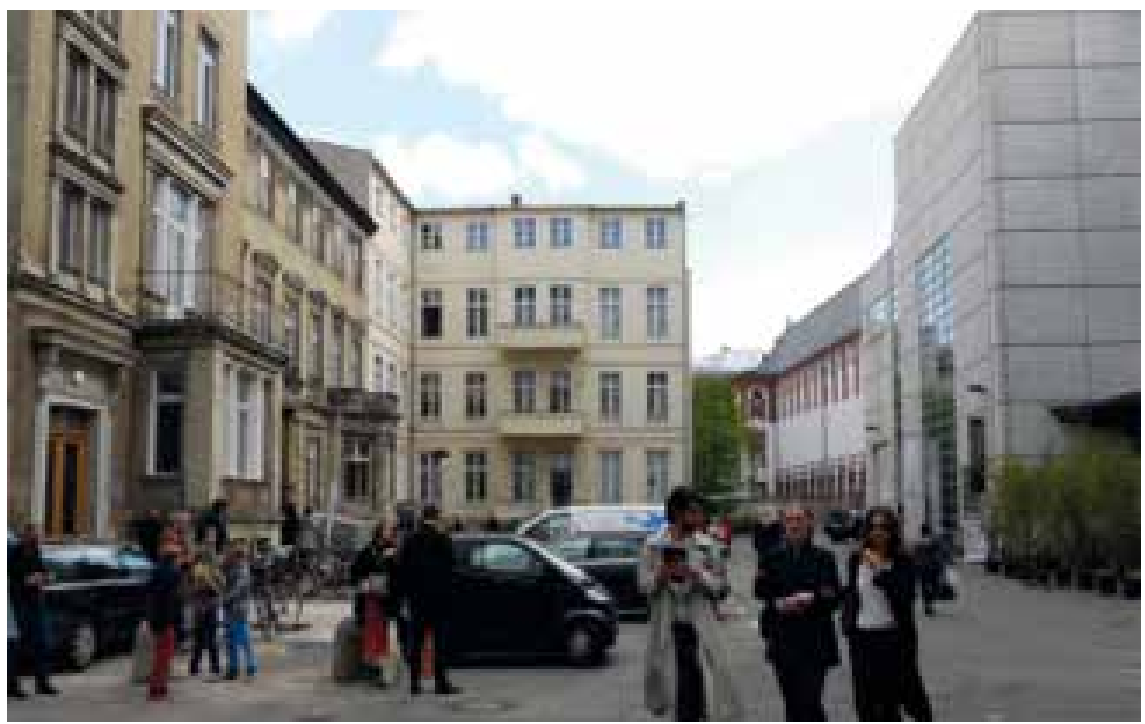

Fig. 10. Art galleries in Berlin 2013 (photo Kaisa Broner-Bauer)

seek their ways to places where this is possible. A tolerant atmosphere feeding creativity often arises in sufficiently big cities characterized by multinationality and multiculturalism. When organizations offering jobs and searching for the best employees, for instance technology or media enterprises, move to the same places as creative people, dynamic synergy is developed, which is the basic criterion of urban vitality. In today's Europe, Berlin is an example of such a place.

\section{THE INTELLECTUAL'S RESPONSIBILITY AND THE STARTING POINT OF URBAN PLANNING TODAY}

According to Edgar Morin, the only hope of saving our civilization from destruction is to change our thinking and take concrete responsibility for the state of the world. Other representatives of the international intelligentsia have also expressed corresponding views. Edward Saïd, the recently-deceased, New York based Palestinian professor of literature, discussed in his book Representations of the Intellectual (1994) ${ }^{26}$ what it means to be an intellectual today According to him, one of the intellec-

26 Edward Saï, Ajattelevan ihmisen vastuu (Helsinki: Loki-Kirjat, 2001). 
tual's tasks is to break down the stereotypes and simplified categories which limit people's thinking and mutual intercourse. Saïd also said that we should give up our conception of literature having tight borders between nations and consider all literature to be "world literature".

Analogically, it is possible to see correspondence between contemporary literature and urban development. About cities we could also say that today they all aim at being multicultural world cities rather than national centres. Earlier, there were only a few real world cities in the world. Today, even small cities, the ones with vitality, are turning into multinational and multicultural metropolises. This has its consequences on the level of urban planning, too.

However, it has to be understood that not all kinds of internationalism work in urban space. Minority nationalities and migrants, in fact all different social, cultural or economic groups, should be given the possibility of expressing their own cultures in the city. Instead of aiming at subordinating them to main culture, preconditions for forming urban mosaic identity should be created. Only in this way do culturally vital places develop, which can offer soil for economic life as well. Forced integration of sub-cultures makes urban-cultural development shallow and may lead to hostility. Cultural richness of world cities like New York and Paris, their creative energy, is hidden in the fact that their multinationality and multiculturalism have to a great extent been capable of developing spontaneously. What would Manhattan be without its ethnic urban villages, in which the memory of the European city also lives? One day, there could be, for instance, a Somali district even in a Nordic city. Conflicts - if they are not prolonged - feed creativity. Dynamic urban development turns even conflicting forces of change into a vital historical movement. I call this kind of creative urban process of change "urban dialectics". 27

In our present-day thinking, it is essential that the starting point of urban planning is not an imaginary urban vision or utopian prediction of the future, but the existing city. Its identity with its different historical layers is a process in which we take part by leaving in it a multi-dimensional layer of our own time. Urban planning always has to deal with the process of change of urban identity. Too radical changes, or changes realized too fast, damage the essential nature of a city and may cause 
deep, incurable wounds. That is why it is important to understand what the factors are that strengthen the identity of the city in positive ways, and to protect them.

We also have to remember that the existing built environment is an invaluable part of our cultural heritage. Its protection and care as well as functional and infill development in accordance with the principles of sustainability are our responsibility today. I refer to the philosopher Martin Heidegger who has written about the meaning of being a human on the earth. In the words of Heidegger, being a human means to dwell "on the earth and under the sky." (...) "Only if we are capable of dwelling, only then can we build." More precisely, according to Heidegger, "mortals dwell in that they save the earth." But saving the earth does not mean exploiting and wearing it out or mastering it, not to mention subjugation. In accordance, "the basic character of dwelling is to spare, to preserve." 28

\section{CONCLUSIONS}

Is there still a particularly European conception of the city? Yes and no. From the external point of view only, all the significant cities of the globe tend to become similar international and multicultural "collage cities". On a deeper level, however, regarding the cultural substructure and local cultural meanings, there are profound differences. The Japanese or Indian city has a totally different cultural substructure from the European one. Despite the programmatic destruction of old parts of cities caused by modern city planning projects, and despite today's globalism and related phenomena, the ideal of the European urban culture is again well and truly alive.

The traditional European urban culture is something unique in the world. The still extant historic cities or parts of them in the old continent are ever inspiring urban environments in today's society, too. The "modern" conception of the city put emphasis on regulation, economic calculation and separate urban functions, which caused impoverishment of the urban character and did not match with the idea of the traditional city. Harsh critique of the principles of modern urban planning in the

28 Martin Heidegger, "Building Dwelling Thinking”, Poetry, Language, Thought (New York: Perennial Library, 1975), 147-150. 


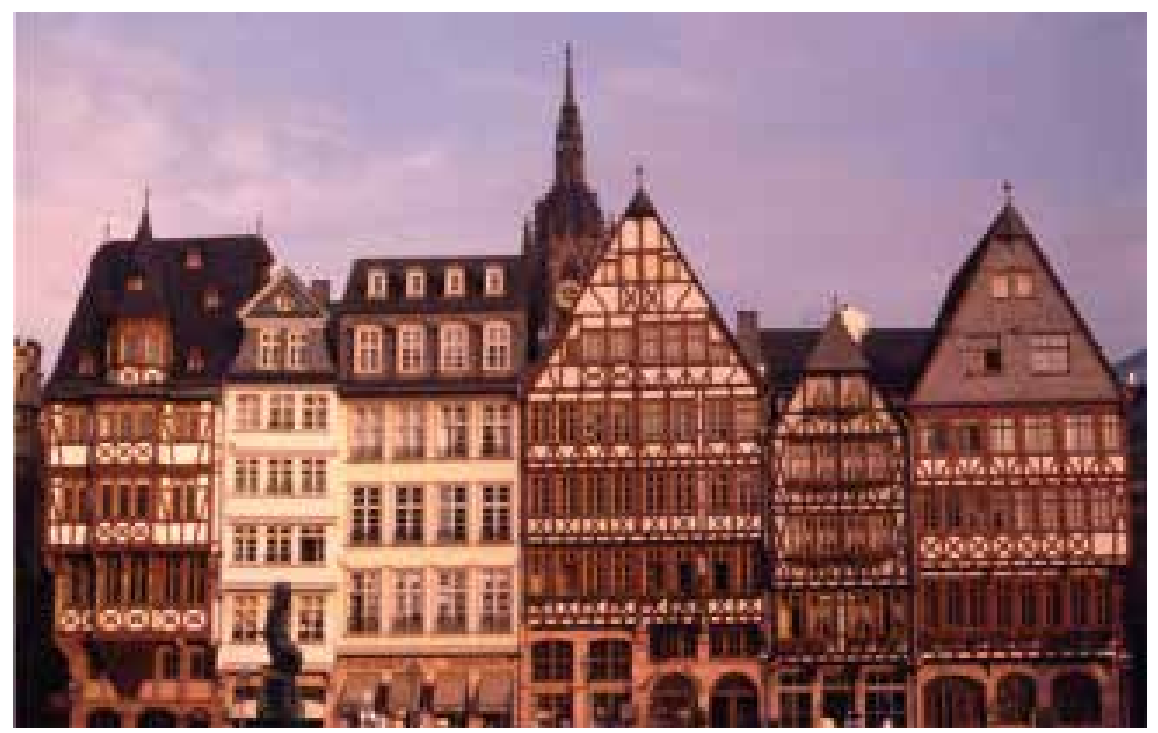

Fig. 11. Frankfurt - Römerberg, reconstructed medieval buildings after bombings of the Second World War (photo Kaisa Broner-Bauer)

second half of the $20^{\text {th }}$ century has brought out a new understanding of the nature of the city. Preservation planning along with criteria for sustainability has become an accepted approach to deal with the problems of the change process of the contemporary city.

With the coming of post-modern culture and information society, new urban phenomena have appeared. We now live in time of the internet, in which a placeless network of contacts is central, not only on the scale of a city, region or country, but on the scale of the whole globe. Ours is the time of global exchange, with which unparalleled demographic mobility and global mixing of cultures are connected. The last-mentioned feature has earlier been a phenomenon of "world cities" only. Today, even small cities tend to be multicultural while at the same time being more and more exposed to the effects of a global economy. New centres are arising and many old ones lose their importance. The opposition of metropolis and periphery has become an outdated concept.

New types of cities develop, most often not by the building of completely new environments, but rather by transforming extant environments in interaction with old and new, and as a result of a new kind of synergy. In the process of environmental and societal change, the question about the cities' identities has become an important factor in the global compe- 
tition for flows of both money and people. Tolerant living environments inspiring creativity function as magnets, whereby identity, creativity, interaction and sustainability are the key words. There is a huge amount of creativity on the level of the inhabitants of the city. This creativity should be brought out, thereby influencing the mosaic identity-forming process of the whole urban community. We need a better multicultural understanding, more sensitivity to local and grass-root urban phenomena, and interaction between city planners and communities, in order to allow the creative contribution of inhabitants to express itself and appropriate the city space.

Kaisa Broner-Bauer: Quo Vadis Civitas? - Thoughts on the European Conception of the City Today

KEYWORDS: CONCEPTION OF THE CITY, SUSTAINABILITY, IDENTITY OF PLACE, MOSAIC IDENTITY, URBAN INTERACTION

\section{SUMMARY:}

The article deals with the change of paradigms in European urban thinking through time. The principles of Modern City Planning of the first half of the $20^{\text {th }}$ century, which despised the classical ideals of the European city and of historical urban environments, as well as the subsequent advent of their counterplot, i.e. the approach of integrated conservation and preservation planning, are seen as the two main opposing tendencies of city development in the last 100 years. They have preceded and prepared the way for a new urban consciousness which puts emphasis on the principles of sustainable development in both global and local terms. While the pressing demands for sustainability have been taken into consideration and even recorded in the law on a certain level in most European countries at the turn of this century, there are still many other new-type urban phenomena which express the present-day tendencies of change in our city-life. The breaking of the traditional space-time relationship due to the arrival of the Internet and the multicultural post-modern urban nomadism, which both go togeth- 
er with a tremendous worldwide economic, social, and environmental restructuration, are among them. As a result, the concept of place has lost its former meaning as an explicitly physical scene. At the same time, mentally, socially and culturally processed issues, such as the identity of a place, have become more and more important putting emphasis on the type of interaction between different people and the places of their lives. Thus the question of dwelling and the expression of multi-cultural identities have become fundamental urban issues. Today in Europe city planning is often less concerned with building new environments than with transforming extant environments and creating interaction and synergy between old and new. Multicultural and tolerant living environments with different historical, social and cultural layers function as magnets for creative people and for inspiring city-life.

\section{CV:}

Kaisa Broner-Bauer is an architect D.Sc. (Tech./Arch.), and professor emerita of Architecture at the University of Oulu, Finland. She has studied and worked in Finland, France, the United States, and Japan and is the author of numerous publications on architecture, historic preservation, and urban studies. Her present research interests include the questions of identity and transcendence in architecture and the built environment. 
